Note

\title{
IMPACT OF THE NUMBER OF Spodoptera frugiperda EGG LAYERS ON PARASITISM BY Trichogramma atopovirilia
}

\author{
Eduardo Barbosa Beserra; José Roberto Postali Parra²* \\ ${ }^{1}$ Universidade Estadual da Paraíba, Depto. Farmácia e Biologia, C.P. 781/791 - 58100-001 - Campina Grande, \\ $P B$ - Brasil. \\ ${ }^{2}$ USP/ESALQ, Depto. Entomologia, Fitopatologia e Zoologia Agrícola, C.P. 9 - 13418-900 - Piracicaba, SP - \\ Brasil. \\ *Corresponding author <jrpparra@esalq.usp.br >
}

\begin{abstract}
Egg parasitoids of the genus Trichogramma (Hymenoptera: Trichogrammatidae) can be found in several crops attacking Spodoptera frugiperda (J. E. Smith, 1797) (Lepidoptera: Noctuidae) eggs. It is therefore necessary to demonstrate the capacity of these natural enemies in suppressing populations of the pest to allow them to be used in biological control programs against that species. This work had the objective of evaluating the impact of egg layer distribution in $S$. frugiperda egg masses on the parasitism capacity of Trichogramma atopovirilia Oatman \& Platner, 1983. Masses containing one, two, and three layers were used as treatments, and 1.6 parasitoid per egg of the pest were released. Parasitism percentage differences were observed among the three types of masses under study, on average $66.24 \pm 8.56 \%, 45.20 \pm 6.20 \%$, and $40.10 \pm 3.46 \%$ for egg masses with one, two, and three layers, respectively, demonstrating the potential of use of the parasitoid for the control of fall armyworm.
\end{abstract}

Key words: Insecta, fall armyworm, egg parasitoid, biological control

\section{IMPACTO DO NÚMERO DE CAMADAS DE OVOS DE Spodoptera frugiperda NO PARASITISMO POR Trichogramma atopovirilia}

\begin{abstract}
RESUMO: Parasitóides de ovos do gênero Trichogramma (Hymenoptera: Trichogrammatidae) ocorrem em diversas culturas atacando ovos de Spodoptera frugiperda (J. E. Smith, 1797) (Lepidoptera: Noctuidae) sendo necessário que se demonstre a capacidade desses inimigos naturais em suprimir a população da praga para que eles possam ser utilizados em programas de controle biológico daquela espécie. O trabalho teve como objetivo avaliar o impacto da distribuição dos ovos em camadas nas posturas de $S$. frugiperda sobre a capacidade de parasitismo de Trichogramma atopovirilia Oatman \& Platner, 1983. Foram utilizadas como tratamentos posturas com uma, duas e três camadas e liberado 1.6 parasitóide por ovo da praga. Observaram-se diferenças quanto à porcentagem de parasitismo entre os três tipos de posturas estudados, sendo em média de 66,24 \pm 8,56\%, 45,20 \pm 6,20\% e 40,10 \pm 3,46\% para posturas com uma, duas e três camadas respectivamente, mostrando o potencial de utilização do parasitóide para o controle da lagarta-do-cartucho do milho.

Palavras-chave: Insecta, lagarta-do-cartucho-do-milho, parasitóide de ovos, controle biológico
\end{abstract}

\section{INTRODUCTION}

Egg parasitoids of the genus Trichogramma (Hymenoptera: Trichogrammatidae) can be found worldwide, in a diversity of crops and hosts, preferentially in the order Lepidoptera, including a great number of agriculturally important pests (Hassan, 1994; 1997), such as Spodoptera frugiperda (J. E. Smith, 1797) (Lepidoptera: Noctuidae), which is considered the main pest of corn in Brazil. The presence of Trichogramma atopovirilia Oatman \& Platner, 1983 parasitizing eggs of that pest in corn crops demonstrates the potential of use of this parasitoid for the control of S. frugiperda (Zucchi et al., 1991; Alvarez \& Roa, 1995; Zucchi \& Monteiro, 1997; Beserra et al., 2002).
In biological control programs involving parasitoid release, it is essential to demonstrate the natural enemy's potential to suppress a pest population (Van Hezewijk et al., 2000). However, it has been observed that S. frugiperda egg masses parasitized by Trichogramma under field conditions are rare (Rueda \& Victoria, 1993); some authors have questioned its use as a control agent, due to the fact that the eggs of the pest are arranged in superimposed layers, and to the presence of scales that make the parasitoid action harder (Toonders \& Sánchez, 1987; Sifontes et al., 1988; Armas \& Ayala, 1993; Beserra et al., 2002). Beserra et al. (2002) observed a low parasitism (2.21\%) of $S$. frugiperda eggs in corn; the species Trichogramma pretiosum Riley, 1879 was the most abundant and occurred in $93.79 \%$ of the samples, while $T$. 
atopovirilia only represented $2.07 \%$. Even in young rice plants, where egg masses are relatively small, parasitism by Trichogramma is difficult, since only 20 to $40 \%$ of the eggs are accessible for parasitism (Sifontes et al., 1988). The presence of scales over Spodoptera exigua (Hübner, 1808) egg masses constitutes a barrier against parasitism by Trichogramma spp. (Greenberg et al., 1998). However, a study conducted by those authors in a cotton field artificially infested with $S$. exigua egg masses, followed by release of $T$. pretiosum and Trichogramma minutum Riley, 1879, resulted in parasitism of $36.8 \%$ and $32.5 \%$, respectively, demonstrating the potential of use of these parasitoids in controling the pest.

The difficulty in finding $S$. frugiperda egg masses parasitized by Trichogramma species can be overcome by using a more aggressive parasitoid, capable of breaking the physical barrier imposed by the presence of layers and scales on the eggs of this pest, as, for example, $T$. atopovirilia (Rueda \& Victoria, 1993). According to these authors, from a total of 1,305 S. frugiperda collected eggs, $42.1 \%$ were parasitized by this species, and among them four masses had a parasitism rate higher than $80 \%$. More in-depth studies on the role and importance of Trichogramma species found on S. frugiperda eggs are required, so that a suitable species can be selected to be multiplied in the laboratory, aiming at the biological control of this pest. Therefore, due to the necessity of finding an alternative for the chemical control of this pest, the objective of this research was to evaluate the impact of egg layer distribution in $S$. frugiperda egg masses on the parasitism capacity of $T$. atopovirilia, a parasitoid of this pest, which, although less frequent in the field, is superior to T. pretiosum in laboratory tests (Beserra et al., 2002).

\section{MATERIAL AND METHODS}

Iron-framed cages covered with tulle fabric (1.5 $\times 1.1 \times 1.5 \mathrm{~cm}$ ) were used in order to evaluate the parasitism capacity of $T$. atopovirilia in a shade-netting structure. Five corn plants with ages between 25 and 30 days were maintained in each cage; one freshly laid (0- 12 hours) $S$. frugiperda egg mass was attached to the adaxial surface of the last upper leaf of each plant with a pin; a glass vial $(8.5 \mathrm{~cm} \times 2.5 \mathrm{~cm})$ containing newly-emerged parasitoids was attached to the middle part of the most central plant (Figure 1). Egg masses containing one, two, or three layers were used as treatments, without taking into account the presence or absence of scales over the masses. The number of eggs in the layered egg masses was estimated by multiplying the number of eggs in the upper layer by the number of layers, and then adding up the eggs on the margins of subsequent layers (Leuck \& Perkins 1972; Nalin 1991). Based on this estimate, 1.6 T. atopovirilia individuals was released per egg (Lopes,

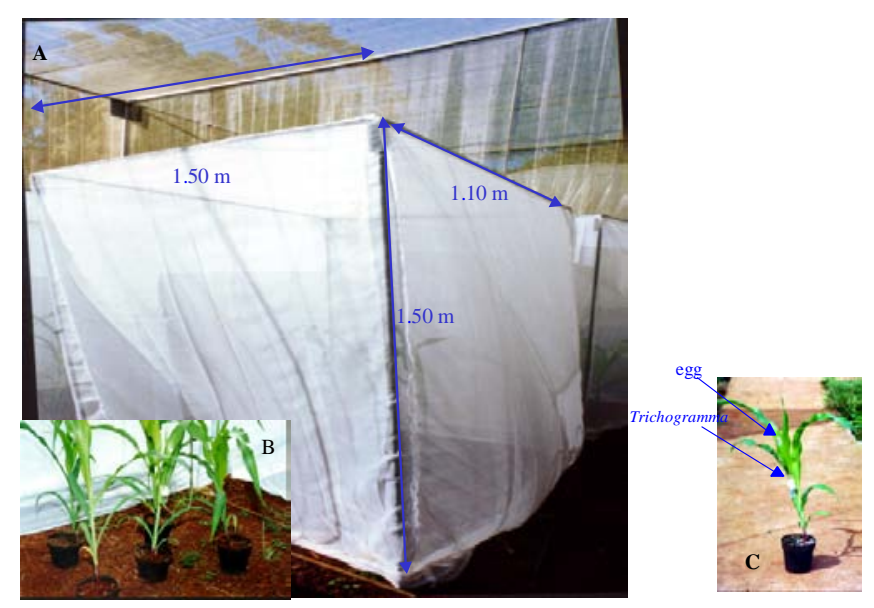

Figure 1 - A) Cage used to evaluate the parasitism capacity of $T$. atopovirilia in a shade-netting structure; B) Distribution of corn plants within the cage; C) S. frugiperda egg mass position in the plant and site of release of T. atopovirilia.

1989). Releases were performed during six consecutive days, using two cages per treatment/day, totaling 36 plots, always in the morning, between 9:00 and 10:00 am; plants were replaced as needed prior to each release. The egg masses were taken to the laboratory 24 hours after the releases, and the total number of eggs was counted based on the number of hatched caterpillars and parasitized eggs. The experimental results were analyzed in a random block design with three treatments (egg mass types) and six replicates (release days); treatment means were submitted to analysis of variance and then compared by the Tukey test $(P<0.05)$.

\section{RESULTS AND DISCUSSION}

There were parasitism percentage differences between the treatment containing a single egg layer and those with two or three layers; there were no differences, however, between treatments with two and three layers (Table 1). The higher parasitism percentage in egg masses containing a single layer was due to the access of females to all eggs in the mass, and consequently to the ease by which they were able to examine and parasitize them; this was not possible in egg masses containing two or three layers, where parasitism occurred only in external eggs, not covered by higher layers. The number of parasitized eggs was not different among the three treatments, which is justifiable because even though there was a higher number of eggs in masses containing two and three layers (on average 144.5 and 206.3, respectively) in relation to single-layer ones (average of 89.53), the insect was unable to parasitize concealed eggs (Beserra, 2000). These results show that T. atopovirilia (and probably other species as well) is unable to parasitize layered eggs; this reduces the efficiency of this species in the control of $S$. frugiperda. 
Table 1 - Parasitism capacity of Trichogramma atopovirilia on Spodoptera frugiperda egg masses with different numbers of layers in a shade-netting structure. Piracicaba, SP.

\begin{tabular}{lcccccc}
\hline Egg mass & $\mathrm{N}$ & $\begin{array}{c}\text { Estimated number } \\
\text { of eggs }\end{array}$ & $\begin{array}{c}\text { Actual number } \\
\text { of eggs }^{2}\end{array}$ & $\begin{array}{c}\text { Number of T. atopovirilia } \\
\text { released }\end{array}$ & \multicolumn{2}{c}{\begin{tabular}{c} 
Parasitism capacity \\
\cline { 4 - 6 } eggs $^{4 ; 5}$
\end{tabular}} \\
\hline One layer & 12 & 447.66 & 447.66 & 716.26 & $285.58 \pm 45.92 \mathrm{a}$ & $66.24 \pm 8.56 \mathrm{a}$ \\
Two layers & 12 & 867.33 & 660.17 & $1,387.67$ & $285.17 \pm 38.29 \mathrm{a}$ & $45.20 \pm 6.20 \mathrm{~b}$ \\
Three layers & 12 & $1,232.42$ & $1,008.42$ & $1,977.25$ & $384.42 \pm 44.33 \mathrm{a}$ & $40.10 \pm 3.46 \mathrm{~b}$ \\
\hline
\end{tabular}

${ }^{1}$ Mean number of eggs estimated according to methodology by Leuck \& Perkins (1972) and Nalin (1991).

${ }^{2}$ Actual number of eggs, obtained based on the number of hatched caterpillars and parasitized eggs

${ }^{3}$ Mean number of T. atopovirilia released, based on the estimated number of eggs per egg mass. (1.6 Trichogramma released/S. frugiperda egg).

${ }^{4,6}$ Data transformed to $\sqrt{\mathrm{x}}$.

${ }^{5,7}$ Means followed by a common letter are not different by Tukey test $(P<0.05)$.

Considering the difficulty with which $T$. atopovirilia parasitizes layered eggs in S. frugiperda egg masses, the parasitism percentages here obtained were high as compared to those observed under field conditions by Greenberg et al. (1998) for T. pretiosum and Trichogramma maidis Pintureau \& Voegelé on S. exigua egg masses, with values of $36.8 \%$ and $34.5 \%$, respectively, and by Toonders \& Sánchez (1987), who, after releasing Trichogramma sp. in the field to control $S$. frugiperda, verified parasitism in the order of $4 \%$, which is justified by a great number of brachypterous individuals, decreasing the dispersal capacity of the parasitoid. In this case, predation by ants also occurred, in addition to rainfall, which together affected parasitism by Trichogramma sp.

In the present research, the action of competitors and other external factors were eliminated in the shadenetting structure, which could have favored the parasitoid performance. On the other hand, the data relative to egg masses containing two and three layers presented differences between the estimated and actual numbers of eggs in the egg mass, and produced a number of $T$. atopovirilia released per $S$. frugiperda egg higher than 1.6 individual (Table 1). This fact probably contributed toward a higher parasitism pressure and an increased percentage of parasitized eggs in masses with two or three layers. Therefore, the parasitism results were overestimated in the present research for $S$. frugiperda egg masses containing two or three layers.

However, parasitism can be high in single-layer egg masses (Table 1); even in egg masses containing two or three layers, the parasitism percentage was higher than the values found thus far (Table 1); therefore, the action of T. atopovirilia, together with the action of other egg parasitoids such as Telenomus remus or Chelonus insularis, an egg-caterpillar parasitoid (Cruz, 1995; 2000), and larval and pupal parasitoids such as Campoletis flavicincta and Archytas incertus (Cruz, 1995; 2000; Milward-de-Azevedo et al., 1991), in addition to preda- tors such as Doru luteipes (Cruz, 1995; 2000), could be sufficient to avert applications of chemical products in corn, which are very frequent.

On the other hand, a higher proportion of parasitoids, superior to that used in this research (1.6 parasitoid per egg of the pest), could also contribute to increase parasitism of T. atopovirilia on S. frugiperda eggs under field conditions, even in masses containing a single layer of eggs.

\section{REFERENCES}

ALVAREZ, L.R.; ROA, F.G. Comportamiento parasítico de Telenomus sp. en Spodoptera frugiperda. Revista Colombiana de Entomologia, v.21, p.191-196, 1995.

ARMAS, J.L.; AYALA, J.L. Parasitic behavior, biology, reproduction, and field utilization of Telenomus sp. a native parasitoid of Spodoptera frugiperda in Cuba. Trichogramma News, n.7, p.24, 1993.

BESERRA, E.B. Bioecologia, etologia e capacidade de parasitismo de Trichogramma spp. visando ao controle biológico de Spodoptera frugiperda (J.E. Smith, 1797). Piracicaba: USP/ESALQ, 2000. 132p. (Tese - Doutorado).

BESERRA, E.B.; DIAS, C.T. dos S.; PARRA, J.R.P. Distribution and natural parasitism of Spodoptera frugiperda (Lepidoptera: Noctuidae) eggs at different phenological stages of corn. Florida Entomologist, v.85, p.588593, 2002.

CRUZ, I. Manejo integrado de pragas do milho com ênfase para o controle biológico. In: CICLO DE PALESTRAS SOBRE CONTROLE BIOLÓGICO DE PRAGAS, 4., Campinas, 1995. Anais. Campinas: SEB, 1995. p.48-92.

CRUZ, I. Métodos de criação de agentes entomófagos de Spodoptera frugiperda (J. E. Smith). In: BUENO, V.H.P. (Ed.) Controle biológico de pragas: Produção massal e controle de qualidade. Lavras: Ed. UFLA, 2000. cap.7, p.111-136.

GREENBERG, S.M.; SUMMY, K.R.; RAULSTON, J.R.; NORDLUND, D.A. Parasitism of beet armyworm by T. pretiosum and T. minutum under laboratory and field conditions. Southwestern Entomologist, v.23, p.183-188, 1998.

HASSAN, S.A. Strategies to select Trichogramma species for use in biological control. In: WAJNBERG, E.; HASSAN, S.A. (Ed.) Biological control with egg parasitoids. Wallingford: CAB International, 1994. p.55-72.

HASSAN, S.A. Seleção de espécies de Trichogramma para o uso em programas de controle biológico. In: PARRA, J.R.P.; ZUCCHI, R.A. (Ed.) Trichogramma e o controle biológico aplicado. Piracicaba: FEALQ, 1997. cap.7, p.183-206.

LEUCK, D.B.; PERKINS, W.D. A method of estimating fall armyworm progeny reduction when evaluating control achived host-plant resistance. Journal of Economic Entomology, v.65, p.482-483, 1972. 
LOPES, J.R.S. Estudos bioetológicos de Trichogramma galloi Zucchi, 1988 (Hym., Trichogrammatidae) para o controle de Diatraea saccharalis (Fabr., 1794) (Lep., Pyralidae). Piracicaba: USP/ESALQ, 1989. 141p. (Dissertação - Mestrado).

MILWARD-DE-AZEVEDO, E.M.V.; PARRA, J.R.P.; GUIMARÃES, J.H. Aspectos da biologia de Archytas incertus e suas inter-relações com $S$. frugiperda. 2. Carga parasitária e região de "inoculação” no corpo do hospedeiro. Revista Brasileira de Entomologia, v.25, p.499-507, 1991.

NALIN, D.M. Biologia, nutrição quantitativa e controle de qualidade de populações de Spodoptera frugiperda (J. E. Smith, 1797) (Lepidoptera: Noctuidae) em duas dietas artificiais. Piracicaba: USP/ESALQ, 1991. 150p. (Tese - Doutorado).

RUEDA, O.C.P.; VICTORIA, C.A.C. Evaluation de la efetividad de Trichogramma atopovirilia Oatman y Platner sobre Spodoptera frugiperda (J. E. Smith) en maiz, en condiciones del Valle del Cauca. Palmira: Universidade Nacional de Colombia, 1993. 64p. (Tese Graduação).

SIFONTES, J.L.A.; OBREGON, J.R.; CUELLAR, S.R.; GARCÍA, J.L.A. Hábitos oviposicionales de Spodoptera frugiperda (J. E. Smith) (Lepidoptera: Noctuidae) en plantas de arroz. Revista Centro Agrícola, v.15, p.11-15, 1988.
TOONDERS, T.J.; SÁNCHEZ, J.L.C. Evaluacion de la efectividad de Trichogramma spp. (Hymenoptera: Trichogrammatidae) en el combate de Spodoptera frugiperda (J. E. Smith) (Lepidoptera: Noctuidae) recomendaciones para su uso. Centro de Entomologia y Acarologia, p.75-84, 1987.

VAN HEZEWIJK, B.H.; BOURCHIER, R.S.; SMITH, S.M. Searching speed of Trichogramma minutum and its potential as a measure of parasitoid quality. Biological Control, v.17, p.139-146, 2000.

ZUCCHI, R.A.; MONTEIRO, R.C. O gênero Trichogramma na América do Sul. In: PARRA, J.R.P.; ZUCCHI, R.A. (Ed.) Trichogramma e o controle biológico aplicado. Piracicaba: FEALQ, 1997. cap. 2, p.4166.

ZUCCHI, R.A.; PARRA, J.R.P.; SILVEIRA NETO, S. Trichogramma species associated with some lepidopterous pests in Brazil. Les Colloques l'INRA, n.56, p.131-134, 1991.

Received January 19, 2004

Accepted January 28, 2005 